\title{
Appreciation
}

\section{Tribute to Dr. P. T. de Silva}

Journal of the Ceylon College of Physicians, 2015, 46, 60-61

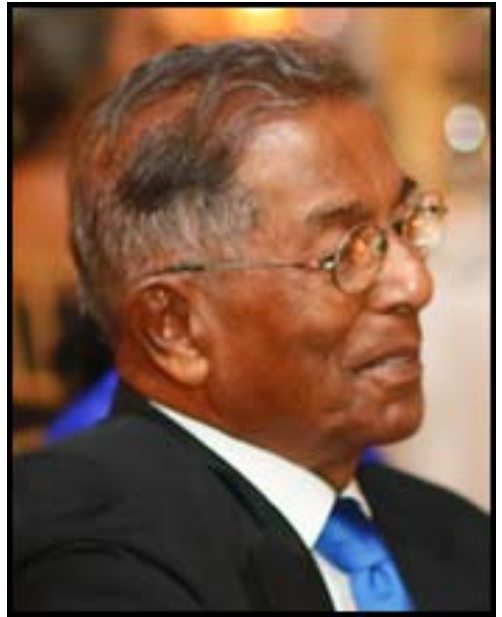

Dr. Primus Tillakaratne de Silva (fondly called PT) was a much loved and respected physician. He passed away on $28^{\text {th }}$ of February 2015, after a brief illness aged 85 years. His interest in medicine never waned. He was up to date and continued to offer his services to his loyal patients until about 2 weeks prior to his death.

He was born to traditional Buddhist parents in Mahawewa, Chilaw. He had his primary and secondary education at Nalanda Vidyalaya in Colombo from where he entered the Faculty of Medicine, Colombo. His contemporaries in the medical school were Dr. Yoheswaran, Dr. Malinga Fernando, Dr. Maheshwaran and Dr. Haththotuwa. Most of his batchmates predeceased him.

Following his success at the M. D. examination held by the University of Ceylon, he proceeded to the United Kingdom, where he was successful at the MRCP examination. On return to Sri Lanka he worked briefly at the General Hospital, Jaffna and Colombo South Hospitals until he was appointed as consultant physician, in General Hospital, Colombo. He reached the peak of his professional career when he was selected as the president of the Ceylon College of Physicians in 1984.

My association with Dr. P. T. began in 1977 when I was relief house officer of the General Hospital, Colombo. I was transferred from the accident service to work as senior house officer, in medicine in ward 45 under Dr. P. T. de Silva. To me, it was a wonderful experience to treat the genuinely sick, after the unpleasant experience of treating traumatic injuries sustained after falls, brawls or road traffic accidents especially under the influence of alcohol.

There were no registrars or senior registrars at that time - only the consultant, senior house officer and intern house officer. Dr. P. T. de Silva did a complete ward round daily. He treated all patients alike, irrespective of their status. The attention and the time each patient received depended entirely on the severity of the illness or how puzzling the clinical problem was. I was directly responsible to him for the care of his patients. He was readily available for any advice and always replied my telephone calls promptly.

Dr. P. T. de Silva had a special interest in gastroenterology. He was the first physician to perform sigmoidoscopy at the bedside in the General Hospital, Colombo. He was a superb physician with a remarkable clinical acumen and sound diagnostic skills. He was always cheerful and had a pleasant bedside manner. He managed his patients with minimal investigations and treated them with the minimum number of drugs. He rejected polypharmacy. His prescriptions were neat, simple and legible.

He had a special flare for teaching undergraduates and encouraged his junior staff to follow postgraduate education. He was a fair and just examiner at undergraduate and postgraduate levels. At the end of each internship appointment, he took us, his medical staff to the Fountain Cafe and encouraged us to eat to our hearts' content. His wife, Kusuma and family joined us at these feasts.

After his retirement from the General Hospital, Colombo he was a familiar figure at Asiri Hospital for many, many years. He drove his car daily, clad in his well known attire of white short sleeved bush shirt, white trousers, with white clogs on his feet. He was very popular with the doctors and nurses at Asiri Hospital for his humour and genial personality. Within hours of hearing about his illness, I rushed to Durdans Hospital to see him. He was on assisted ventilation and I knew that sadly, the end was near.

He was a devoted a family man and enjoyed a sing song at any time. He had a flair for reciting kavi from memory and producing kavi at the spur of the 
moment when needed. He had two brilliant sons and one daughter. The elder son, Janaka, is the professor of medicine at the University of Ragama, and the director of the Postgraduate Institute of Medicine. He specialized in Gastroenterology taking after his father. The younger son, Asitha, is the professor of pharmacology at the University of Ragama.
Dear Sir, you will be sadly missed by your family, friends, numerous patients and doctors in whose training you played a vital role. May you attain the supreme bliss of Nirvana.

\section{Dr. Anula Wijesundere}

